\title{
FORTHCOMING PAPERS
}

The next issue of the British fournal of Nutrition will appear in December. It is hoped to publish in it the following papers:

The nutrition of Nigerian children, with particular reference to their ascorbic-acid requirements. By B. M. NiCOL.

The synthesis of lysine by the lactating goat. By D. C. Edwards and R. A. Darroch.

The role of fat in the diet of rats. 9. Influence on growth and histology of diets with hydrogenated arachis oil or no fat, supplemented with linoleic acid or raw skim milk, and of crude casein compared with Vitamin Test Casein. By E. Aaes-Jørgensen, J. P. Funch, P. F. ENGFL and H. DAM.

Nutrition of the cat. I. A practical stock diet supporting growth and reproduction. By Cecilia D. Dickinson and Patricia P. Scott.

Nutrition of the cat. 2. Protein requirements for growth of weanling kittens and young cats maintained on a mixed diet. By Cecilia D. Dickinson and Patricia P. Scott.

The role of fat in the diet of rats. 10. Influence on reproduction of hydrogenated arachis oil as the sole dietary fat. By E. Aaes-Jørgensen, J. P. Funch and H. Dam.

Changes in composition of the digesta along the alimentary tract of sheep. By A. W. Boyne, Rosa M. Campbell, D. P. Cuthbertson and J. Davidson.

Essential amino-acids of some tropical cereal millets. By N. G. Baptist and B. P. M. Perera.

The rate of passage of fooostuffs through the alimentary tract of the goat. 3 . The intestines. By Eu.zzabeth J. Castle.

The effect of pyridoxin deficiency on certain organs of the rat. By CYNTHIA D. COMBRIDGE.

The relationship between hypovitaminosis $\mathrm{A}$ and the cerebrospinal-fluid pressure in the chick: an experimental study. By D. H. M. Woollam and J. W. Millen.

The effects of chronic undernutrition and of total starvation on growing and adult rats. By Elsie M. Widdowson and R. A. McCance.

Vitamin $\mathrm{C}$ economy of rabbits. By Leslie J. Harris, B. J. Constable, A. N. Howard and AUDREY LEADER. 


\section{(All rights reserved)}

Obituary (Sir Edward Mellanby)

The nutrition of Nigerian children, with particular reference to their energy requirements. By B. M. NicoL

Malnutrition in African adults. 3. Effect of diet on body composition. By E. G. Holmes, E. R. Jones, Margaret D. Lyle and Margaret W. Stanier .

The effect of hexoestrol implantation on growth and certain carcass characteristics of fattening steers. By J. N. AItKen and J. A. CRICHTON

The effect of hexoestrol implantation on the fattening of lambs. By J. C. GiLL, W. Thomson and J. A. Crichton

Experimental dental caries in the albino rat. The production of carious lesions in animals maintained on a finely powdered purified diet containing $67 \%$ sucrose. By R. L. Hartles, F. E. Lawton and G. L. Slack

Disappearance of carotene from the alimentary tract of vitamin A-deficient rats. By V. H. Воотн

The effect of calcium depletion on the chemical composition of bone minerals in laying hens. By T. G. TAYLOR and J. H. MOORE .

Preliminary experiments on the effect of methionine sulphoximine on the developing chick and on transplantable tumours. By THE LATE EDWARd MeLLANBy

\section{INDEX OF AUTHORS}

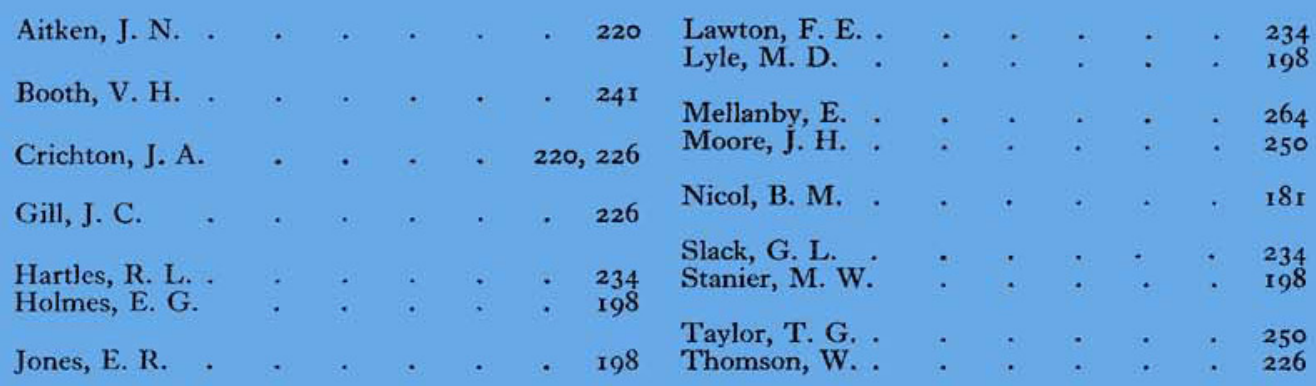

